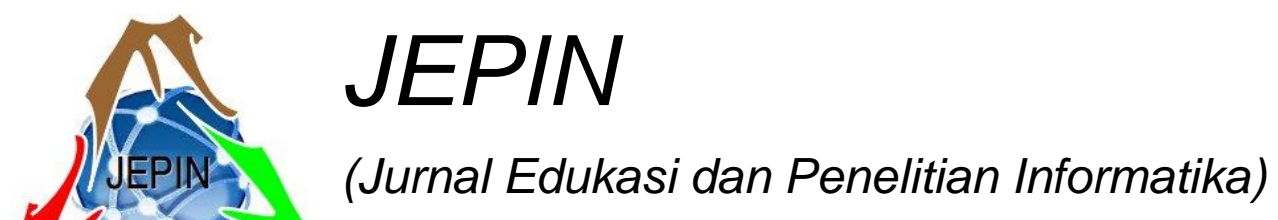

\title{
Implementasi Jaringan VPN untuk Mengurangi Biaya Komunikasi Menggunakan Metode EoIP Over PPTP: Studi Kasus House Printing
}

\author{
Rizka Fauziah Ramdhani" $^{\# 1}$, Raka Yusuf ${ }^{\# 2}$

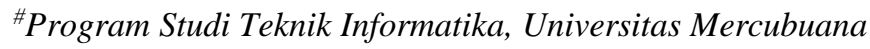 \\ Jl. Meruya Selatan No. 1, Kembangan, Jakarta 11650 \\ ${ }^{1}$ rizkafauziahregmail.com \\ 2raka@mercubuana.ac.id
}

\begin{abstract}
Abstrak - Perusahaan di bidang percetakan masih sangat dibutuhkan, meski dunia digital kini semakin berkembang pesat. Banyak korporasi masih membutuhkan media cetak sebagai penunjang untuk memenuhi kebutuhan perusahaan. House Printing adalah salah satu perusahaan di bidang percetakan yang masih berkembang, dengan perkembangan teknologi saat ini kebutuhan akses data tidak cukup dibebankan dengan akses lokal saja, sehingga dibutuhkannya struktur jaringan yang mampu mengakses data lebih cepat meski dengan jarak jauh sekalipun. Selain itu, koneksi jaringan yang dibutuhkanpun tidak ingin terpaku oleh salah satu provider saja. Sebagai perusahaan industri kreatif yang sedang berkembang dengan mengikuti perkembangan teknologi yang ada, House Printing memiliki tanggung jawab penuh untuk memberi layanan terbaiknya kepada para pelanggannya. Tidak hanya sekedar meliputi produk atau jasa yang ditawarkan, akan tetapi berkaitan dengan akses data dari kantor cabang ke kantor pusat atau sebaliknya. Terlebih dengan kondisi pandemic yang tak kunjung usai, yang mengharuskan karyawan bekerja dari rumah. Dengan file grafis yang memiliki ukuran kapasitas yang cukup besar, sangat menghambat kinerja perusahaan jika hanya transfer data melalui email saja. Selain itu menjadikan pelayanan perusahaan tidak efektif dan kurang memuaskan bagi pelanggan apabila terdapat gangguan jaringan dll, karena tidak dapat akses ke kantor pusat. Dengan menyesuaikan kondisi perusahaan dan kebutuhan dukungan jaringan pada perusahaan, salah satu opsi penyelesaian masalah untuk transfer data agar lebih mudah adalah dengan menggunakan metode VPN atau dengan menggunakan metode Cloud Storage. VPN atau yang disebut juga Virtual Private Network merupakan salah satu alternatif pengaman data yang bersifat privat yang memungkinkan penggunaannya untuk perusahaan berkembang dengan efisiensi biaya untuk perusahaan.
\end{abstract}

Kata kunci - Efisiensi biaya, EoIP, Percetakan, PPTP, VPN.

\section{Pendahuluan}

House Printing merupakan salah satu perusahaan berkembang yang bergerak dibidang percetakan.
Perusahaan yang bergerak dalam bidang media cetak di era industri 4.0 kini membutuhkan kinerja yang lebih cepat dan memori yang lebih kompatibel. Besarnya file grafis sebelum memasuki tahap pencetakan, memerlukan effort lebih untuk saling transfer data baik dari segi jaringan maupun memori data yang lebih besar. Dalam hal ini transfer data dari kantor pusat ke kantor cabang tidak cukup hanya mengandalkan email to email saja.

Beberapa kendala jaringan yang dihadapi perusahaan dan klien kerap kali menjadi hambatan bagi perusahaan untuk berkembang lebih maju lagi. Selain itu menjadikan pelayanan perusahaan tidak efektif dan kurang memuaskan bagi pelanggan apabila terdapat gangguan jaringan dan lain-lain karena tidak dapat akses ke kantor pusat. House Printing memiliki tanggung jawab penuh untuk memberi layanan terbaiknya kepada para pelanggannya. Tidak hanya sekedar meliputi produk atau jasa yang ditawarkan, akan tetapi berkaitan dengan akses data dan jaringan antar cabang. Terlebih dalam kondisi pandemic yang masih belum berakhir, berimbas pada karyawan yang memungkinkan harus bekerja dari rumah masing-masing dan mengambil data klien dari rumah ke PC kantor. Belum lagi dengan kapasitas file yang cukup besar untuk di transfer via email ataupun remote manual.

Penggunaan public network dengan hak dan pengaturan yang sama seperti menggunakan network local merupakan satu keuntungan dari penggunaan VPN. VPN mempunyai beberapa tunneling yang bisa digunakan, diantaranya Point to Point Tunneling Protocol (PPTP) dan Ethernet over IP (EoIP) [1]. Dengan memaksimalkan penggunaan MikroTik untuk mengimplementasikan VPN menggunakan metode EoIP dan didukung dengan metode PPTP. MikroTik sebagai network router menjadi solusi untuk mengontrol penggunaan jaringan yang sesuai aturan dan agar tidak disalah gunakan [2]. Merujuk pada kondisi perusahaan yang memberi limitasi budget pada penunjang kinerja perusahaan, maka metode ini menjadi solusi untuk kinerja yang lebih baik dengan nominal yang dikeluarkan perusahaan tidak terlalu besar. 
Dengan adanya penelitian ini mejadikan metode implementasi VPN agar dapat mengatasi kendala yang ada pada perusahaan. Meski dalam penelitian-penelitian terdahulu, penggunaan VPN dengan metode ini kerap kali menjadi topik hangat penelitian, pada penelitian ini diperbaharui dengan adanya perbandingan harga untuk penerapan VPN dengan berfokus menggunakan paket internet IP dynamic yang lebih memungkinkan dibanding menggunakan paket IP static untuk mengatasi kendala biaya yang ada pada perusahaan. Selanjutnya akan terdapat perbandingan harga sebelum dan sesudah menggunakan VPN pada House Printing ini yang menunjukkan bahwa dengan mengimplementasikan VPN maka pengeluaran biaya bulanan perusahaan cukup berkurang dan menjadikan kinerja karyawan lebih efektif serta lebih efisien.

\section{Metode Penelitian}

VPN adalah teknologi yang memungkinkan interkoneksi dua atau lebih situs jarak jauh melalui infrastruktur, yang sering digunakan bersama oleh publik, seperti Internet [3].

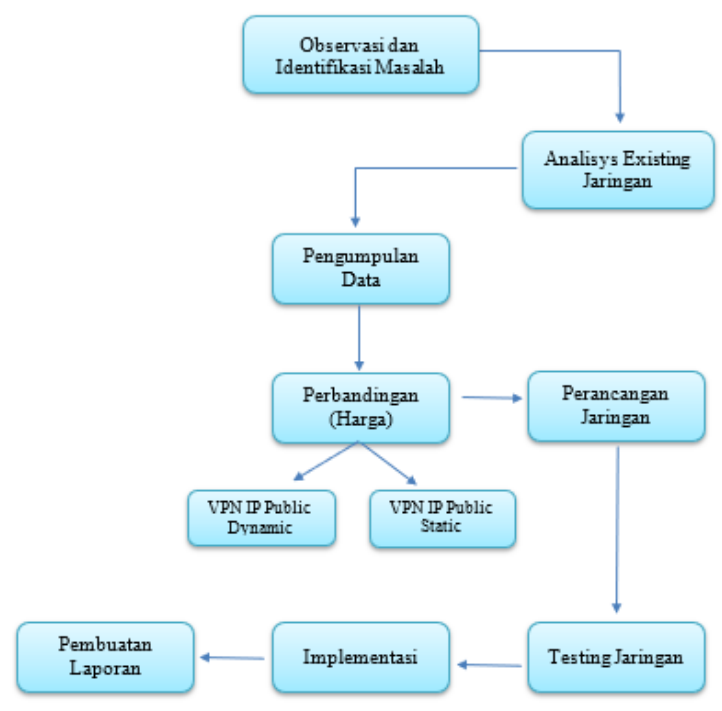

Gambar 1. Tahapan penelitian

Maka metode pengimplementasian VPN pada penelitian ini menggunakan beberapa tahap metode penelitian (lihat Gambar 1), yaitu diantaranya:

\section{A. Observasi dan Identifikasi Masalah}

Untuk menentukan latar belakang masalah pada penelitian ini, peneliti mengidentifikasi kendala jaringan yang ada pada House Printing. Dengan melakukan beberapa metode observasi, maka selanjutnya peneliti akan meninjau beberapa kasus, daftar masalah kemudian diurutkan sesuai dengan tingkat masalah tersebut. Beberapa kasus yang ditemukan seperti kendala transfer data, kendala jaringan hingga kendala over budget pada penggunaan jaringan yang ada pada tiap cabang menjadi suatu kendala yang harus segera diselesaikan agar kinerja perusahaan lebih meningkat lagi.

\section{B. Analisis Existing Jaringan}

Setelah melakukan observasi, maka terkumpul sudah untuk beberapa masalah dan solusi yang akan ditawarkan, selanjutnya pada tahap analisis jaringan yang ada ini, peneliti menganalisis ketersediaan jaringan yang ada pada perusahaan sebelum penerapan metode yang akan digunakan. Gambaran topologi jaringan yang ada pada House Printing dapat dilihat pada Gambar 2.

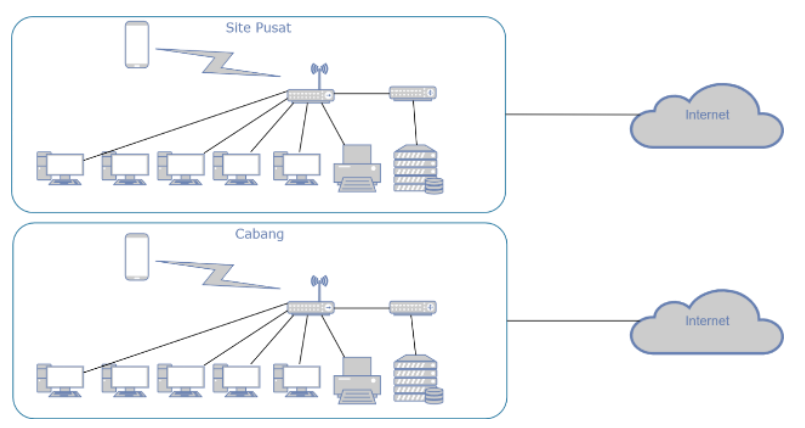

Gambar 2. (Ilustrasi) Jaringan yang ada pada House Printing

Pada topologi ini dijelaskan bahwa kantor pusat dan kantor cabang masih menggunakan paket internet dedicated yang terbilang tidak begitu efektif secara pengeluaran biaya dan kecepatan bandwidth yang digunakan tidak sesuai dengan kebutuhan perusahaan ini, karena penggunaan paket layanan internet yang menggunakan IP Public Static di setiap site-nya (dalam hal ini kantor pusat dan kantor cabang) sehingga pengeluaran yang dibutuhkan untuk biaya komunikasi ini terhitung over budget setiap bulannya.

EoIP merupakan protokol proprietary MikroTik. Penggunaan fitur ini pada antar jaringan yang akan terhubung harus menggunakan router MikroTik yang sama. Jaringan VPN dengan koneksi Internet di server dan sisi klien yang berbeda mempengaruhi stabilitas jaringan yang menggunakan alamat publik [4]. Paket data yang ditransmisikan melalui terowongan dienkapsulasi. Sangat cocok untuk aplikasi yang mengutamakan kecepatan [5]. Dengan menerapkan metode EoIP over PPTP pada perusahaan ini maka diharapkan dapat mengoptimalkan kinerja perusahaan dengan lebih menghemat pengeluaran biaya komunikasi dari sebelum adanya pengimplementasian VPN ini.

\section{Pengumpulan Data}

Untuk melakukan analisis lebih lanjut, peneliti mengumpulkan data sebelum memberi beberapa penawaran solusi. Sebagai perbandingan solusi yang sesuai dengan kebutuhan dan sistem keuangan yang ada di perusahaan agar sesuai dengan hasil penelitian akhir.

Antarmuka EoIP terlihat seperti antarmuka Ethernet biasa (secara logika). Ketika fungsi bridging diaktifkan, semua data yang dikirimkan pada dua router melalui protokol Ethernet akan dijembatani, sama seperti jika 
kedua router dihubungkan dengan kabel. Urutan enkapsulasi pada protokol EoIP adalah mengenkapsulasi layer 3 Internet Protocol (IP) pada layer 2 menggunakan teknologi Ethernet II [6].

Dengan menerapkan teknologi VPN, perusahaan bisa berkomunikasi secara aman melalui jaringan internet dengan biaya lebih minim dibanding dengan solusi sejenis frame relay dan ATM [7]. Pengeluaran biaya untuk pembayaran ISP per-bulan Januari - Oktober 2020 dapat dilihat pada Gambar 3.

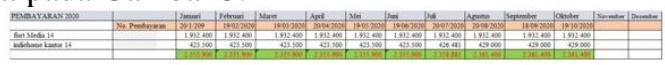

Gambar 3. Cost ISP perusahaan

\section{Perbandingan Harga}

Karena pada penelitian ini berfokus pada efisiensi biaya komunikasi serta penggunaan bandwidth yang sesuai dengan kebutuhan perusahaan maka peneliti melakukan perbandingan harga paket layanan internet untuk menerapkan teknologi VPN ini dengan menggunakan 2 perbandingan harga, yaitu:

1) VPN Menggunakan IP Public Static: Ada banyak tunnel mode yang bisa diimplementasikan, masing-masing dengan karakteristik dan kelebihan serta kekurangannya masing-masing, yang bisa digunakan sesuai kebutuhan, salah satunya dengan menggunakan peralatan router MikroTik. Untuk membuat terowongan, kedua cabang harus terhubung ke Internet dan mempunyai IP publik statis, dan kemudian MikroTik akan membuat jalur pribadi melalui koneksi TCP/IP. Pada tahapan ini diberikan beberapa referensi harga paket layanan yang menyediakan IP Public Static. Referensi harga paket layanan internet dari beberapa ISP (Internet Service Provider) yang terdapat IP Public Static untuk VPN dapat dilihat pada Gambar 4-7.

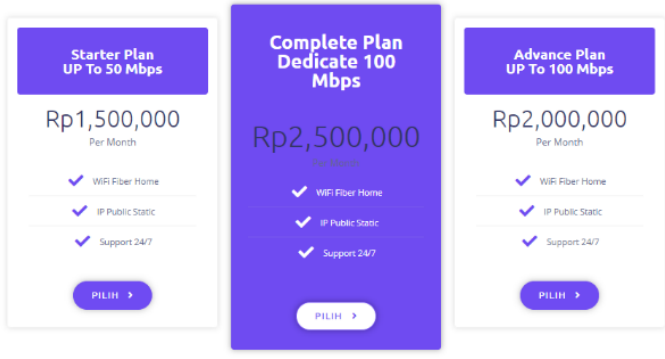

Gambar 4. Daftar harga jaringan internet IP Static

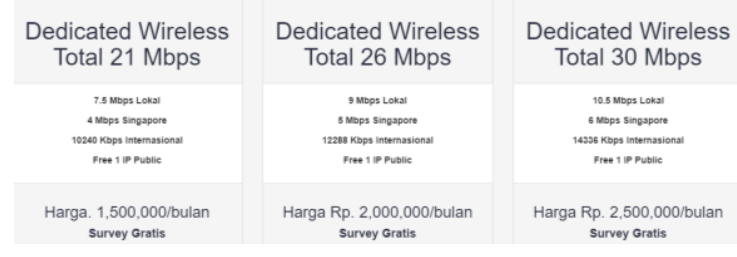

Gambar 5. Daftar harga jaringan internet IP Static

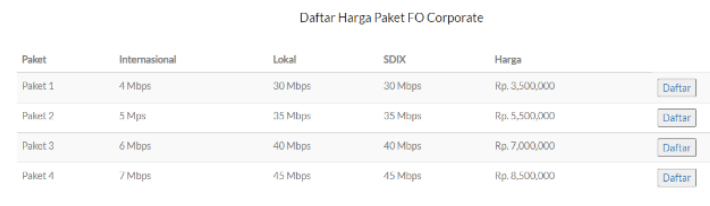

Gambar 6. Daftar harga jaringan internet IP Static

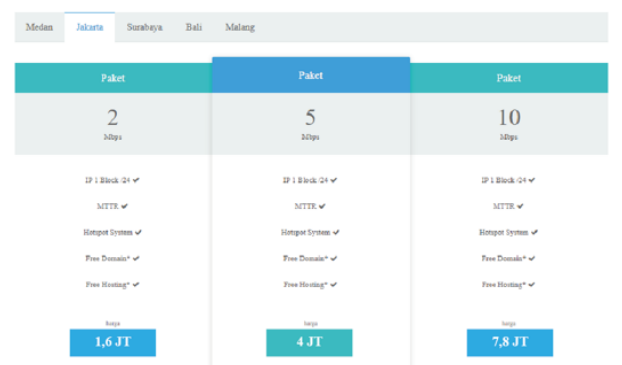

Gambar 7. Daftar harga jaringan internet IP Static

Beberapa kelebihan dari IP Public Static, yaitu:

1) Fix atau Tidak Berubah

2) Stabilitas

3) Untuk Penggunaan Khusus

Beberapa kekurangan dari IP Public Static diantaranya:

1) Tidak Fleksibel

2) Hampir Tidak Menawarkan Solusi

3) Cukup Merepotkan

2) VPN Menggunakan IP Public Dynamic: IP dynamic biasanya dikonfigurasi pada perangkat yang menggunakan protokol DHCP, dan sering berubah. Selanjutnya pada tahapan ini diberikan beberapa referensi harga paket layanan yang menyediakan IP Public Dynamic. Referensi harga paket layanan internet dari beberapa ISP yang terdapat IP Public Dynamic untuk VPN dapat dilihat pada Gambar 8-10.

Untuk data perbandingan VPN ini maka penelitian ini dilakukan dengan memberi metode perbandingan yaitu dengan menggunakan metode Cloud Storage untuk mempermudah transfer data sebagai salah satu opsi lain selain menggunakan VPN. Cloud Storage merupakan bagian dari beberapa sistem virtual yang ada di dalam 1 PC server fisik, dan server virtual ini bisa menjalankan bermacam-macam fungsi server yang berlainan, sebagai contoh: fungsi server DNS, server Oracle, dan server 2 lainnya, jadi menghemat tempat, dan listrik, serta hardware-nya jadi semakin sedikit karena 1 server bisa menjalankan bermacam-macam server yang berbeda dan itu terpisah [8].

Berikut kelebihan dari IP Public Dynamic, yaitu:

1) Keamanan yang Handal

2) Ramah Pengguna

3) Tidak memerlukan biaya terlalu banyak Beberapa kekurangan dari IP Public Dynamic diantaranya:

1) Sulit untuk Mengidentifikasi Gangguan

2) Maitenance Penomeran IP Lebih Sulit

3) Lebih Sulit Untuk Mengecek Client 


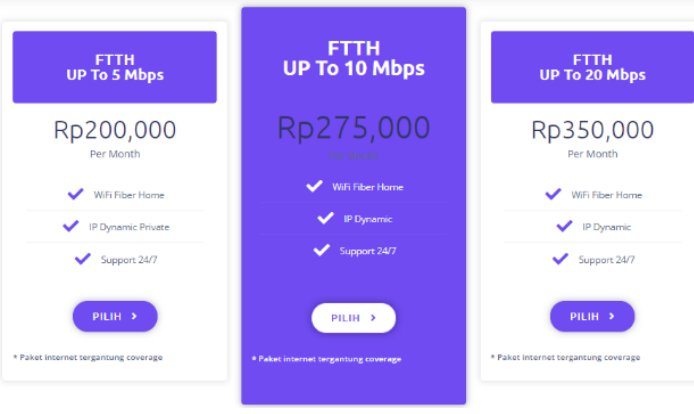

Gambar 8. Daftar harga jaringan internet IP Dynamic

\section{Oxygen Home}

Paket ini ditujukan untuk rumahan.

Kelebihan : Upload stabil

Kekurangan : Internet kurang stabil, IP Private, tidak ada opsi untuk IP statik, routing ke luar negri sering aneh

\begin{tabular}{lccc} 
Paket & \multicolumn{2}{c}{ Daftar Harga Paket Oxygen Home } \\
Download & Upload & Harga/Bulan \\
Home 15 & 15 Mbps & 7 Mbps & Rp. 218.900 \\
Home 25 & 25 Mbps & 12 Mbps & Rp. 273.900 \\
Home 50 & 50 Mbps & 25 Mbps & Rp. 389.900 \\
Home 100 & 100 Mbps & 50 Mbps & Rp. 493.900
\end{tabular}

Gambar 9. Daftar harga jaringan internet IP Dynamic (https://jaranguda.com/harga-paket-internet-fiber-kantor-dan-rumahanoxygen/)

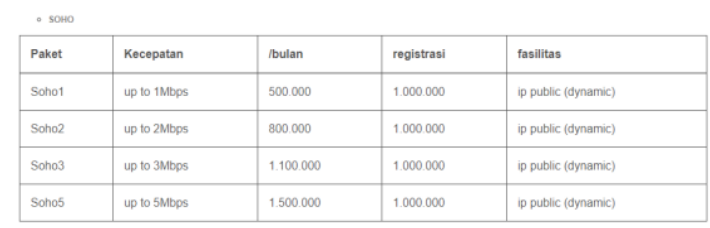

Gambar 10. Daftar harga jaringan internet IP Dynamic (https://sites.google.com/site/palapamediaindonesia/)

1) DropBox: DropBox merupakan salah satu tempat penyimpanan data online terpopuler saat ini karena teknologi yang digunakannya memberikan kemudahan untuk menyimpan data di dalamnya. Sejak 2007, DropBox telah mengumpulkan lebih dari 50 juta pengguna dari seluruh dunia.

Keunggulan:

1) Hampir semua OS populer terdapat Dropbox, seperti Dropbox untuk Windows, Dropbox untuk iOS, Dropbox untuk Android, Dropbox untuk Mac, Dropbox untuk Ubuntu, dll.

2) Berbagi lengkap, tidak seperti berbagi file Dropbox lainnya, yang dapat diunduh langsung secara publik.

3) Kapasitas penyimpanan bisa mencapai $18 \mathrm{~GB}$, tetapi mengundang 32 teman masih agak berat. 1 orang = 500MB. tidak cukup.

Kekurangan:

Kapasitas penyimpanan standar hanya 2 GB.

Biaya:
1) $2 \mathrm{~GB}:$ Gratis.

2) 50GB: US\$9.99/bln atau US\$99/thn.

3) 100GB:US $\$ 19.99 / \mathrm{bln}$ atau US $\$ 199 / \mathrm{thn}$.

4) Unlimited: US\$759/thn (untuk 5 orang, setiap orang dikenakan biaya US\$125/thn).

2) Google Drive: Cloud Data Storage adalah bagian sebuah cloud computing. Pada penelitian Zhang, dkk (2010) menjelaskan bila cloud ialah suatu kumpulan dari beberapa computing resources yang dapat dikonfigurasikan dan dapat diakses darimana saja, selain itu resources-nya dapat dikurangi atau ditambah dengan mudah dan cepat [9]. Cloud storage keluaran Google ini dilengkapi beberapa fitur unggulan. Pengguna Google Drive dapat menyimpan gambar atau foto, aplikasi, video dan segala macam jenis data di dalamnya. Bisa di kolaborasikan dengan berbagai layanan google lainnya. Seperti google apps, google mail, doc, dll, sehingga menjadikan suatu pekerjaan lebih efektif dan efisien.

Kelebihan:

1) Google drive cukup support untuk pengeditan dokumen secara online dari browser.

2) Mendukung banyak file, google drive support hingga 30 macam format file secara langsung melalui browser. Bahkan ketika perangkat lunak tersebut tidak di install pada desktop.

Metode pilihan ini sangat bermanfaat jika Anda seorang designer yang biasa bekerja dengan file berukuran besar seperti penggunaan Adobe Photoshop atau Adobe Illustrator. Sehingga file Anda akan lebih mudah diakses setiap saat dan dimanapun Anda berada.

Kekurangan:

Fitur share link download file tidak tersedia untuk publik, seperti dropbox.

Biaya:
a) 5GB: Gratis
b) $25 \mathrm{~GB}$ : US\$ $2.49 / \mathrm{bln}$.
c) 100GB: US\$ 4.99/bln.
d) 1000GB: US\$ 49.99/bln.
e) 1000GB: US\$ 799.99/bln.

Menimbang dari beberapa perbandingan harga untuk metode cloud storage, maka metode ini tidak sesuai dengan efisiensi cost yang di butuhkan House Printing. Untuk penelitian ini, VPN diusulkan menjadi solusi yang paling tepat dengan menerapkan metode EoIP over PPTP sesuai dengan rujukan beberapa studi literatur yang menjelaskan bahwa metode ini paling tepat untuk di terapkan pada perusahaan yang memiliki kantor cabang yang berjauhan [10].

\section{E. Perancangan Jaringan}

Pada tahapan ini menguji coba seberapa besar peningkatan performa jaringan yang baru dibandingkan dengan jaringan yang lama. Ilustrasi rancangan jaringan untuk House Printing dapat dilihat pada Gambar 11. 


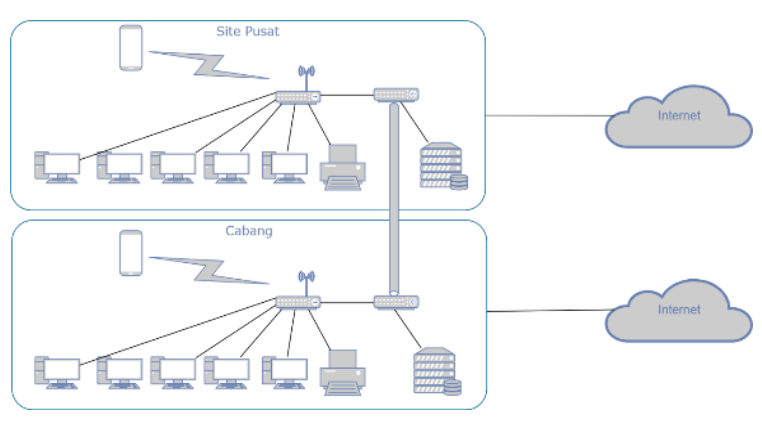

Gambar 11. (Ilustrasi) Rancangan Jaringan untuk House Printing

Tahap pertama dalam mendesign, harus diawali dengan membuat topologi jaringan berbasis MikroTik supaya design lebih focus [11]. Topologi diatas sebagai rancangan jaringan VPN yang akan dibangun dengan menggunakan metode EoIP over PPTP. Dengan menggunakan PPTP sebagai metode tunneling Point to Point dan EoIP sebagai metode tunneling yang menghubungkan routing antar sitenya, dikarenakan tujuan akhir penelitian ini akan menggunakan dynamic IP.

\section{F. Implementasi}

Pada tahapan ini setelah mendapatkan hasil yang bagus pada pengujian dalam perancangan jaringan serta testing jaringan maka tahap selanjutnya adalah implementasi mengganti design dan konfigurasi jaringan lama ke design dan konfigurasi jaringan yang baru. Beberapa perangkat utama yang harus disediakan untuk menjalankan proses implementasi ini dapat dilihat pada Tabel 1.

TABEL I

SPESIFIKASI PERANGKAT ROUTER KANTOR CABANG

\begin{tabular}{|c|c|c|}
\hline Perangkat & Spesifikasi & Keterangan \\
\hline \multirow[t]{14}{*}{ MikroTik } & $\begin{array}{l}\text { Product } \\
\text { code }\end{array}$ & $\begin{array}{c}\text { RB3011UiAS- } \\
\text { RM }\end{array}$ \\
\hline & $\begin{array}{c}\text { Architectur } \\
\mathrm{e}\end{array}$ & ARM 32bit \\
\hline & CPU & IPQ-8064 \\
\hline & $\begin{array}{l}\text { CPU core } \\
\text { count }\end{array}$ & 2 \\
\hline & CPU & \\
\hline & $\begin{array}{l}\text { nominal } \\
\text { frequency }\end{array}$ & $1.4 \mathrm{GHz}$ \\
\hline & Dimensions & $443 \times 92 \times 44$ \\
\hline & $\begin{array}{c}\text { RouterOS } \\
\text { license }\end{array}$ & 5 \\
\hline & $\begin{array}{l}\text { Operating } \\
\text { System }\end{array}$ & $\underline{\text { RouterOS }}$ \\
\hline & $\begin{array}{l}\text { Size of } \\
\text { RAM }\end{array}$ & $1 \mathrm{~GB}$ \\
\hline & $\begin{array}{l}\text { Storage } \\
\text { size }\end{array}$ & $128 \mathrm{MB}$ \\
\hline & $\begin{array}{l}\text { Storage } \\
\text { type }\end{array}$ & NAND \\
\hline & MTBF & $\begin{array}{c}\text { Approximatel } \\
\text { y } 200^{\prime} 000 \\
\text { hours at } 25 \mathrm{C}\end{array}$ \\
\hline & $\begin{array}{c}\text { Tested } \\
\text { ambient } \\
\text { temperature }\end{array}$ & $-20^{\circ} \mathrm{C}$ to $70^{\circ} \mathrm{C}$ \\
\hline
\end{tabular}

\begin{tabular}{ccc}
\hline Perangkat & Spesifikasi & Keterangan \\
\hline & IPsec & \\
& hardware & Yes \\
& acceleratio & \\
& $\mathrm{n}$ & \\
& Product & RB3011UiAS- \\
& code & RM \\
\hline
\end{tabular}

Data pada Tabel 1 merupakan rincian spesifikasi perangkat yang akan digunakan untuk konfigurasi di kantor cabang.

TABEL III

SPESIFIKASI ROUTER KANTOR PUSAT

\begin{tabular}{|c|c|c|}
\hline Perangkat & Spesifikasi & Keterangan \\
\hline \multirow[t]{16}{*}{ MikroTik } & Product code & RB750Gr3 \\
\hline & Architecture & MMIPS \\
\hline & CPU & MT7621A \\
\hline & $\begin{array}{l}\text { CPU core } \\
\text { count }\end{array}$ & 2 \\
\hline & $\begin{array}{l}\text { CPU nominal } \\
\text { frequency }\end{array}$ & $880 \mathrm{MHz}$ \\
\hline & $\begin{array}{l}\text { CPU Threads } \\
\text { count }\end{array}$ & 4 \\
\hline & Dimensions & $113 \times 89 \times 28 \mathrm{~mm}$ \\
\hline & $\begin{array}{c}\text { RouterOS } \\
\text { license }\end{array}$ & 4 \\
\hline & $\begin{array}{c}\text { Operating } \\
\text { System }\end{array}$ & $\underline{\text { RouterOS }}$ \\
\hline & Size of RAM & $256 \mathrm{MB}$ \\
\hline & Storage size & $16 \mathrm{MB}$ \\
\hline & Storage type & FLASH \\
\hline & & Approximately \\
\hline & MTBF & $\begin{array}{c}100^{\prime} 000 \text { hours } \\
\text { at } 25 \mathrm{C}\end{array}$ \\
\hline & $\begin{array}{c}\text { Tested } \\
\text { ambient } \\
\text { temperature } \\
\text { IPsec }\end{array}$ & $-40^{\circ} \mathrm{C}$ to $60^{\circ} \mathrm{C}$ \\
\hline & $\begin{array}{c}\text { hardware } \\
\text { acceleration }\end{array}$ & Yes \\
\hline
\end{tabular}

Data pada Tabel 2 merupakan rincian spesifikasi perangkat yang akan digunakan untuk konfigurasi di kantor pusat.

\section{G. Testing Jaringan}

Pada tahap testing jaringan ini dilakukan setelah tahap perancangan topologi jaringan selesai agar koneksi jaringan dapat dipastikan aman sebelum memasuki tahap implementasi selanjutnya [12]. Hasil testing jaringan untuk transfer data dari pusat ke cabang dapat dilihat pada Gambar 12.

Testing ini dilakukan untuk memastikan apakah network dikedua sisi sudah saling bisa di akses, dan melakukan testing untuk mengukur berapa besar kecepatan yang akan didapat. Hasil transfer file yang dilakukan sebelumnya dengan kapasitas file kurang lebih 300MB (lihat Gambar 13). 


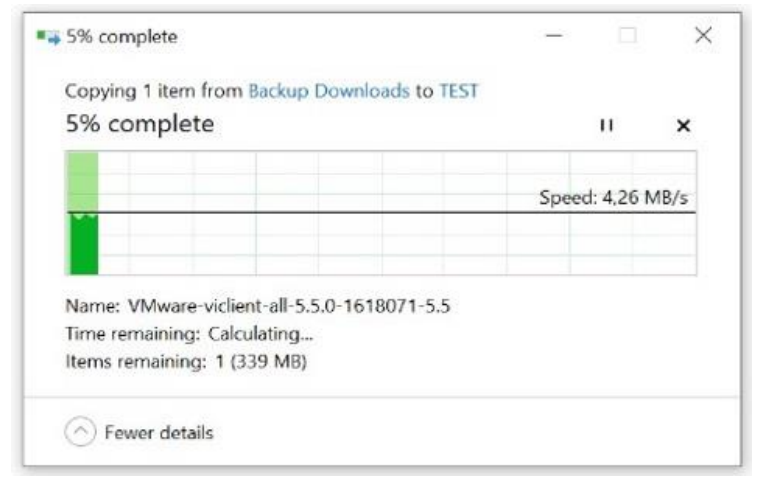

Gambar 12. Testing transfer data

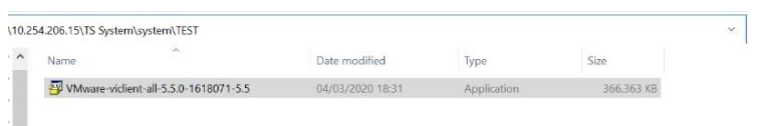

Gambar 13. Kapasitas file yang dikirim

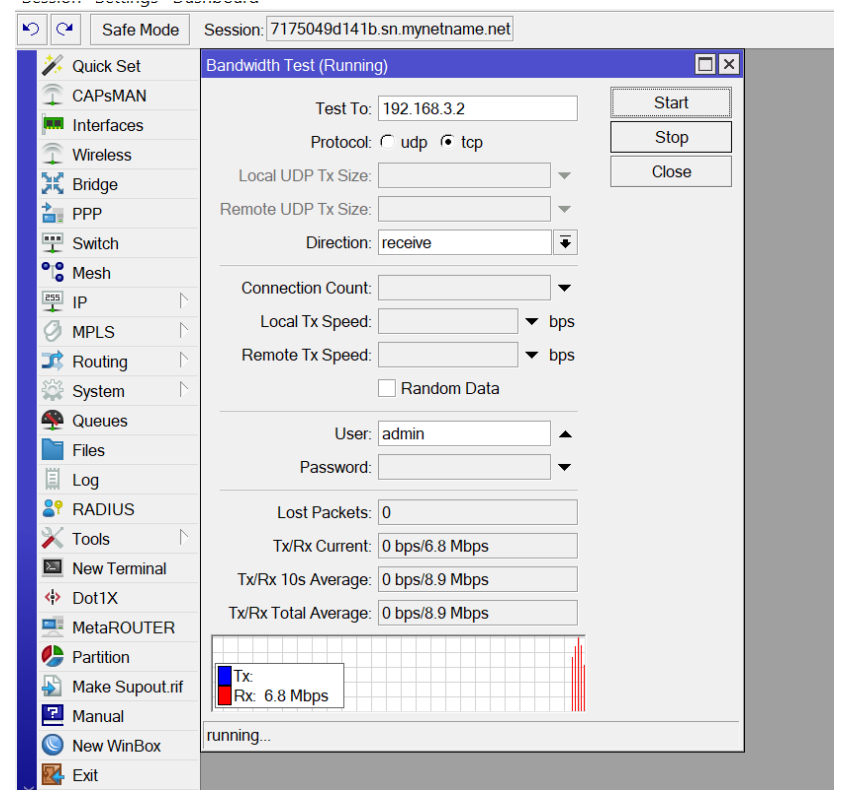

Gambar 14. Monitoring receive dari pusat ke cabang setelah menggunakan VPN

Hasil test download dari pusat ke cabang dengan menggunakan fitur bandwidth test MikroTik setelah menggunakan VPN dapat dilihat pada Gambar 14.

Hasil test upload dari pusat ke cabang dengan menggunakan fitur bandwidth test MikroTik setelah menggunakan VPN. Pada gambar terlihat jelas traffic dan besaran file dalam proses testing ini (lihat Gambar 15). Dengan mengaplikasikan VPN, maka transfer data antar cabang bisa lebih cepat dan lebih efektif untuk kinerja perusahaan.

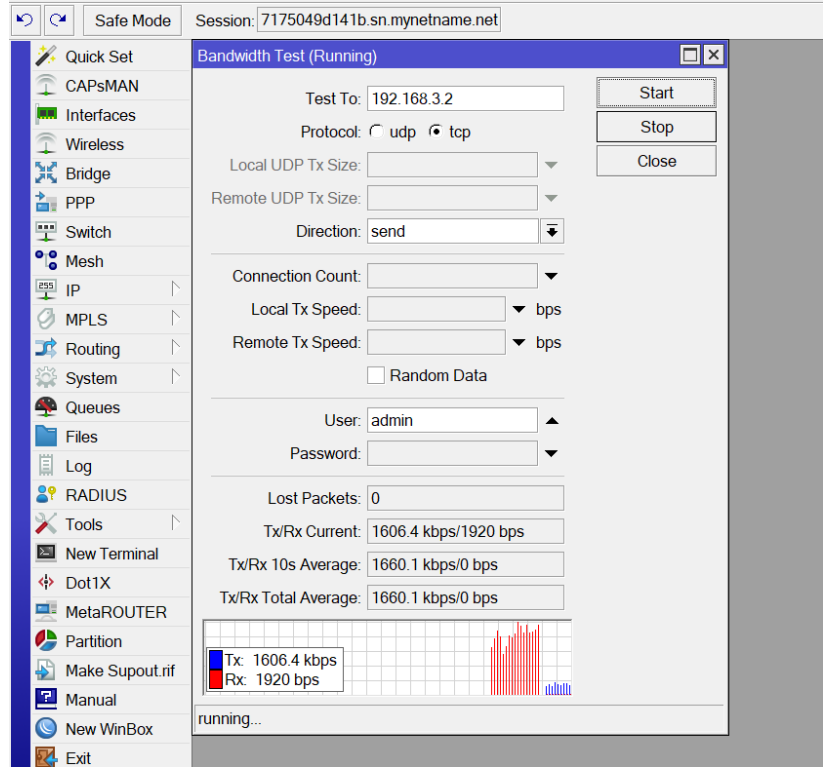

Gambar 15. Monitoring send bandwidth dari pusat ke cabang

\section{HASIL DAN PEMBAHASAN}

Hasil dan pembahasan pada penelitian kali ini merupakan tahapan dalam membahas intisari dari penelitian yang berisi konfigurasi VPN dengan menerapkan EoIP over PPTP dan pernghitungan biaya komunikasi yang dikeluarkan perusahaan sebelum dan sesudah menggunakan VPN. Konfigurasi terdiri dari beberapa tahapan konfigurasi untuk mengkoneksikan dari kantor pusat ke kantor cabang [13].

Dengan menggunakan perangkat yang telah disebutkan di atas, maka selanjutnya melakukan proses konfigurasi untuk menjalankan koneksi antar cabang sesuai dengan simulasi testing jaringan yang telah dilakukan sebelumnya.

\section{A. Konfigurasi PPTP Site Pusat}

Putra, Indriyani, dan Angraini (2018) Hasil penelitiannya menunjukkan bahwa keamanan jaringan komputer dengan metode VPN dan PPTP dapat mempermudah pekerjaan departemen IT, serta dapat mengontrol dan menyelesaikan masalah jaringan perusahaan dari jarak jauh tanpa harus langsung ke lokasi. Selain itu, jaringan VPN ini juga dapat digunakan untuk pertukaran file. Maka, pekerjaan akan menjadi lebih efisien [14].

Konfigurasi DNS Name sebagai metode translate IP Public dynamic yang didapat dari ISP agar dapat diakses dari ISP lain tanpa harus menggunakan IP Public Static (lihat Gambar 16).

Melakukan konfigurasi account PPTP Tunneling di sisi router pusat sebagai jembatan untuk koneksi dari cabang ke pusat (lihat Gambar 17).

Konfigurasi pengaktifan server PPTP pada router pusat agar account yang sebelumnya dibuat dapat digunakan dan dapat terkoneksi ke router pusat (lihat Gambar 18). 

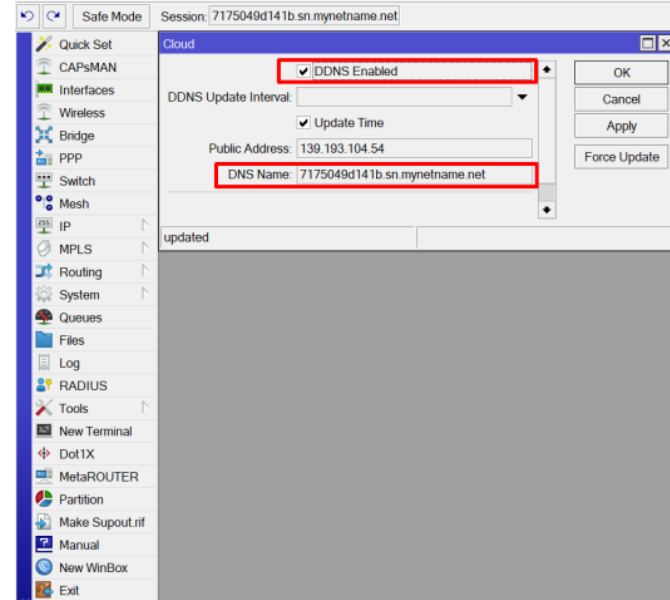

Gambar 16. Konfigurasi DNS Name

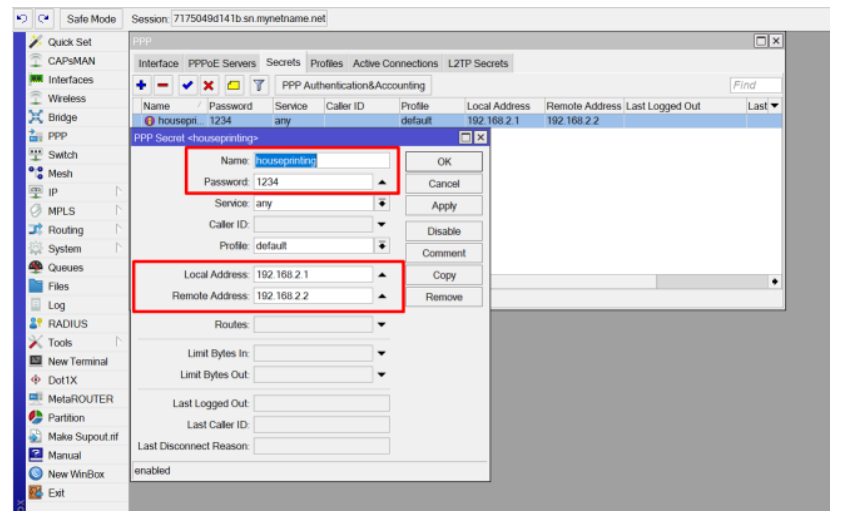

Gambar 17. Enable PPTP server untuk menjadikan konfigurasi PPTP di site pusat sebagai server

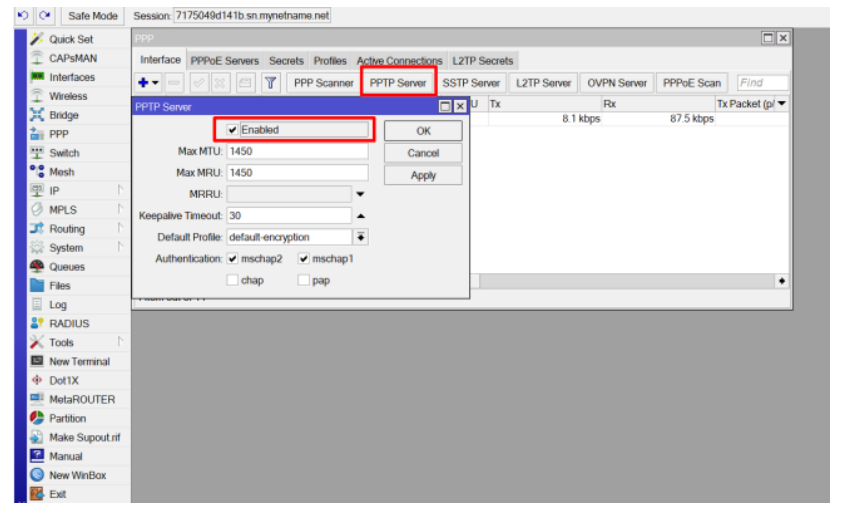

Gambar 18. Pengaktifan koneksi PPTP server pada router pusat

Konfigurasikan client PPTP pada router cabang dengan mencantumkan DNS Name yang sebelumnya dikonversi dari IP dynamic router pusat (lihat Gambar 19). PPTP juga dapat digunakan untuk jaringan pribadi LAN-keLAN dan komputer yang terhubung ke LAN untuk membuat VPN di LAN. Keuntungan utama menggunakan PPTP adalah Anda dapat menggunakan jaringan telepon umum (PSTN) untuk membangun VPN. PPTP murah dan mudah digunakan, dan banyak digunakan sebagai solusi untuk pengguna jarak jauh dan pengguna seluler karena
PPTP menyediakan keamanan dan enkripsi untuk komunikasi di PSTN atau Internet.

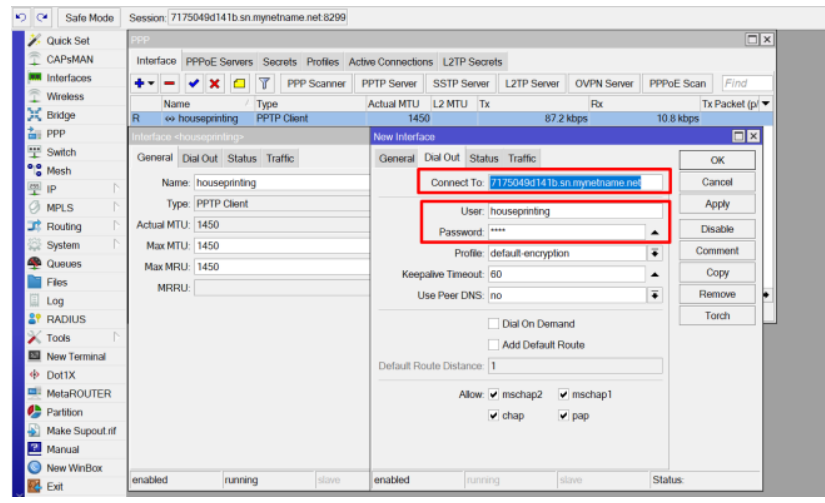

Gambar 19. Konfigurasi PPTP client pada router cabang

\section{B. Konfigurasi EoIP Tunnel disisi Pusat ke Cabang}

Setelah konfigurasi PPTP site pusat, maka selanjutnya kita konfigurasi EoIP Tunnel disisi Pusat ke Cabang (lihat Gambar 20).

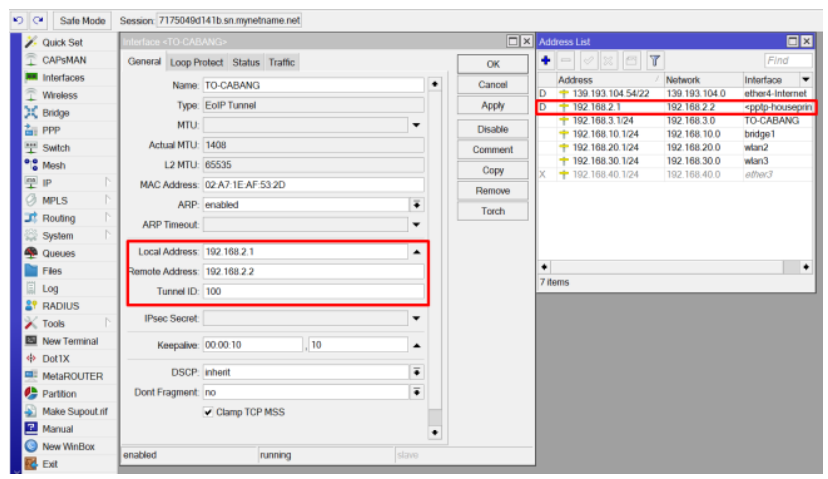

Gambar 20. Konfigurasi EoIP Tunnel disisi pusat ke cabang

Konfigurasi EOIP pada router pusat ke cabang menggunakan IP point to point yang sebelumnya kita buat menggunakan PPTP Tunneling sebagai jalur routing dari router pusat ke cabang agar router pusat dapat mengakses network yang berada pada router cabang agar user dapat lebih mudah akses ke PC yang berada di router cabang dan juga sebaliknya [15].

\section{Konfigurasi EoIP Tunnel Site Cabang to Pusat}

Pada tahap ini, diperlukan EoIP Tunnel dari site cabang ke site pusat agar saling terhubung (lihat Gambar 21).

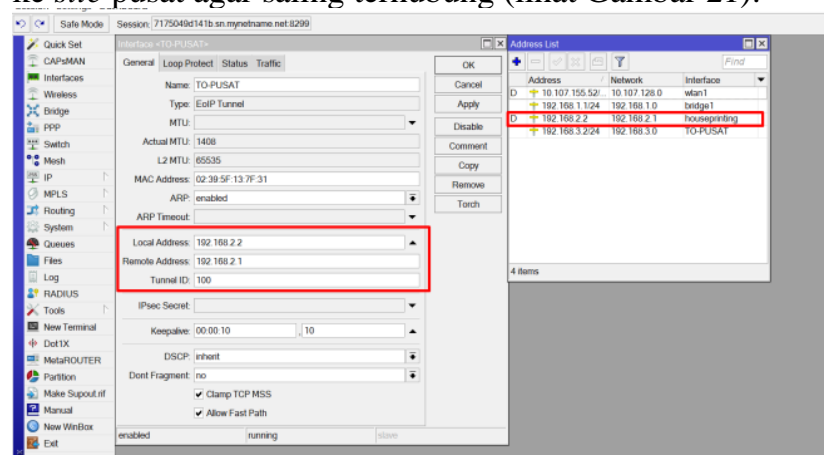

Gambar 21. Konfigurasi EoIP Tunnel disisi cabang ke pusat. 
Pada tahap ini untuk tunnel id haruslah sama di masingmasing site agar tunnel bisa terkoneksi.

\section{Konfigurasi IP Point to Point kea rah Cabang via interface EoIP Tunnel}

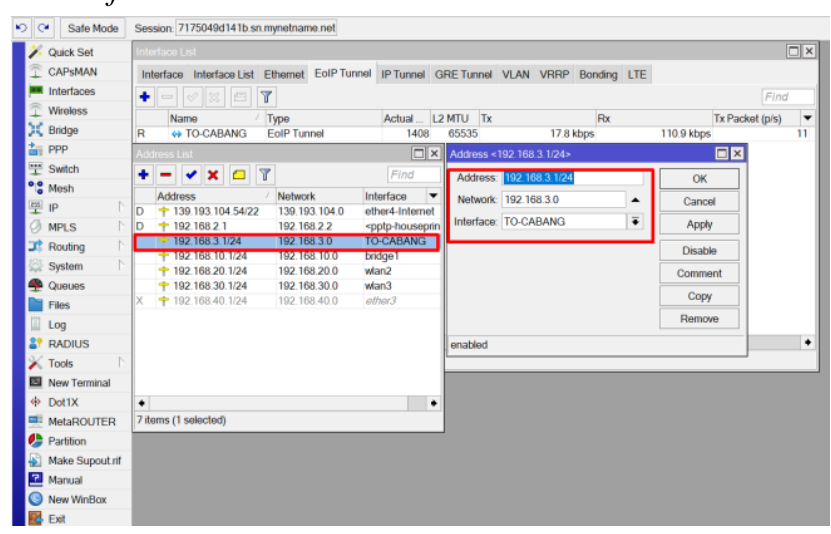

Gambar 22. konfigurasi IP Point to Point di sisi Pusat to Cabang via Interface EOIP Tunnel.

Pembuatan IP Point to Point di sisi router pusat kearah router cabang yang di lewatkan di interface EOIP Tunnel yang sebelumnya dibuat, yang bertujuan sebagai tanda pengenal masing-masing site agar dapat terhubung (lihat Gambar 22).

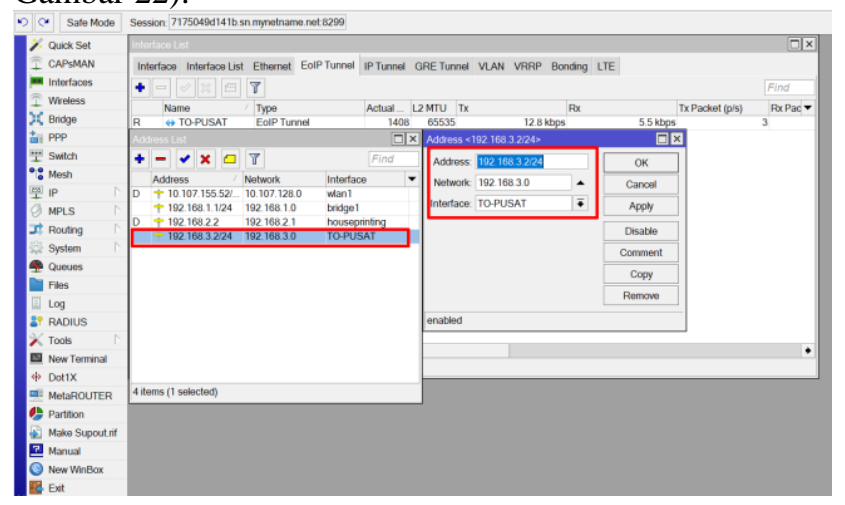

Gambar 23. Konfigurasi IP Point to Point di sisi Cabang to Pusat via Interface EOIP Tunnel

Pembuatan IP Point to Point di sisi router pusat kearah router cabang yang di lewatkan di interface EOIP Tunnel yang sebelumnya dibuat, yang bertujuan sebagai tanda pengenal masing-masing site agar dapat terhubung (lihat Gambar 23).

Test ping dari site pusat ke site cabang, dimana network IP private (IP local) disisi cabang 192.168.3.0/24 dan gatewaynya 192.168.3.2/24, disini kita bisa lihat tanpa adanya static route kearah network cabang site pusat IP local di sisi cabang tidak dapat di ping atau tidak dapat terkoneksi (lihat Gambar 24).

Agar antar site bisa saling akses IP Private (IP Local) masing-masing site maka kita lakukan pembuatan static route agar kita dapat mengakses server aplikasi di masingmasing site (lihat Gambar 25).

Konfigurasi IP Routes network IP Local site cabang dengan keterangan destination address yaitu network IP local site cabang 192.168.1.0/24 diarahkan ke gateway yaitu IP Point to Point EoIP Tunnel site cabang yang sebelum kita buat.

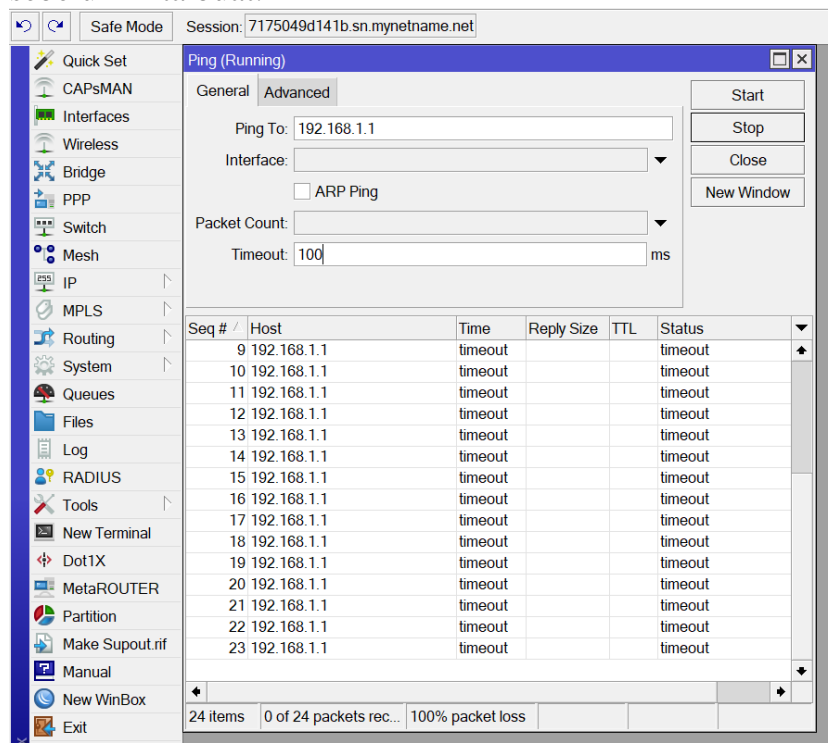

Gambar 24. Test ping dari site pusat ke cabang sebelum dilakukan static routing

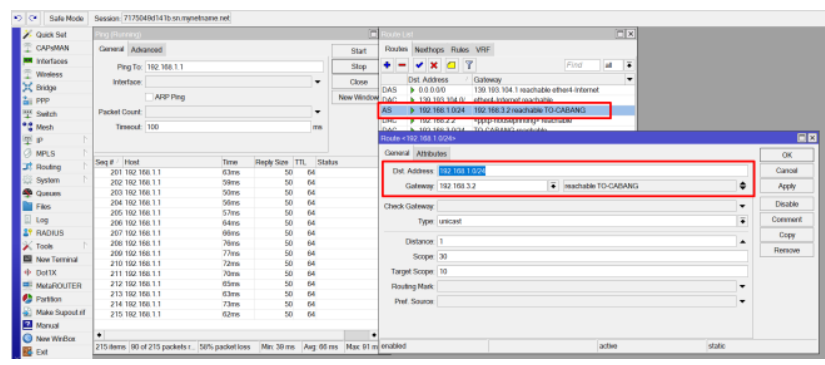

Gambar 25. Konfigurasi static routing network pusat di router cabang

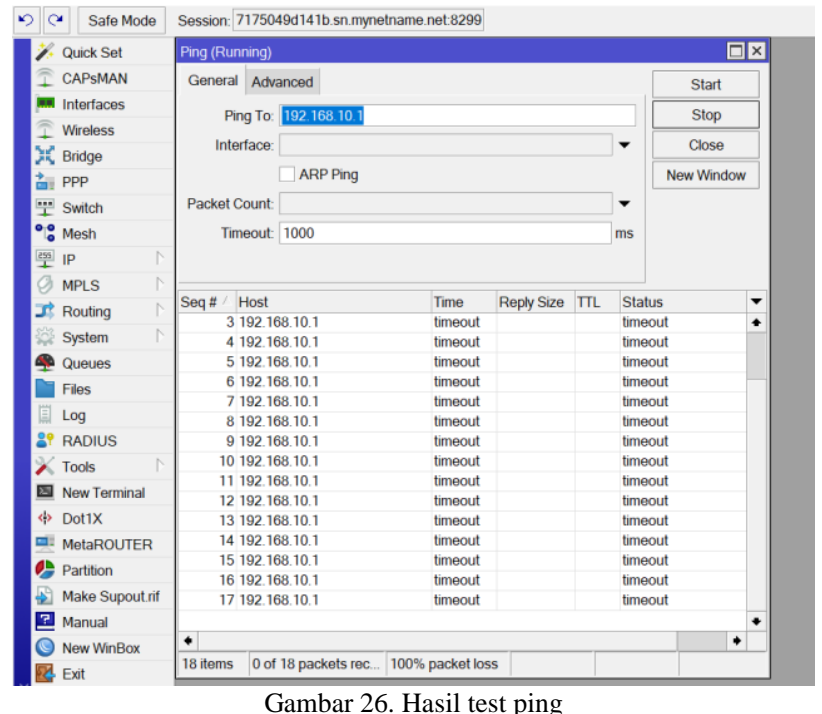

Dari gambar 26 dapat diketahui bahwa hasil test ping dari site pusat kea rah site cabang saat ini sudah dapat diakses.

Gambar 27 merupakan penambahan static route ke arah router pusat, agar router cabang dapat mengakses network pusat. 


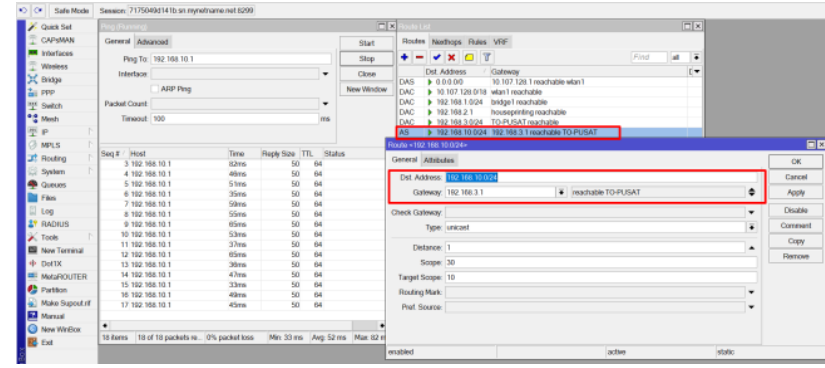

Gambar 27. Konfigurasi static routing network cabang ke pusat

VPN ini menerapkan akses limited ke dalam jaringan yang menggunakan kabel dan router yang sama dengan jaringan publik tanpa mempengaruhi fungsi atau keamanan yang mendasarinya. VPN mendukung setidaknya tiga mode penggunaan yang berbeda:

1. Koneksi klien akses jarak jauh

2. Interkoneksi LAN-to-LAN

3. Akses terkendali Intranet [16].

Metode pemantauan tidak diperlukan dalam penelitian ini, karena pemantauan traffic merupakan metode yang lebih kompleks daripada pemantauan jaringan. Metode ini melihat paket data lalu lintas aktual di jaringan dan menghasilkan laporan berdasarkan lalu lintas jaringan. Program ini tidak hanya dapat mendeteksi peralatan yang rusak, tetapi juga menentukan apakah komponen kelebihan beban atau salah konfigurasi. Kekurangan dari program ini adalah biasanya hanya bekerja pada satu segmen dalam satu waktu; jika perlu mendapatkan data dari segmen jaringan lain perangkat lunak pemantauan harus bergerak di segmen jaringan tersebut, tetapi hal ini dapat diatasi dengan menggunakan agen di jaringan tersebut menggunakan segmen jaringan jarak jauh [16].

Dari data-data spesifikasi perangkat dan konfigurasi diatas, maka dapat dikalkulasikan dengan perbandingan biaya komunikasi yang telah dikeluarkan House Printing dari sebelum menggunakan VPN dan setelah menggunakan VPN dapat dilihat pada Tabel 3.

TABEL IIIII

TABEl PERBANDINGAN HARGA SEBELUM DAN SESUDAH IMPLEMENTAS VPN

\begin{tabular}{|l|l|l|l|}
\hline Ranking & Speed & \multicolumn{1}{|c|}{ ISP } & \multicolumn{1}{|c|}{ Harga } \\
\hline Sebelum & $50 \mathrm{Mbps}$ & First Media & $\begin{array}{l}\mathrm{Rp} \\
1.932 .400,-\end{array}$ \\
\hline Sesudah & $50 \mathrm{Mbps}$ & $\begin{array}{l}\text { PT. Delta } \\
\text { Nusantara }\end{array}$ & $\begin{array}{l}\mathrm{Rp} \\
500.000,-\end{array}$ \\
& & Networks & \\
\hline
\end{tabular}

Terlihat seperti gambar 28 untuk grafik perbandingan harga, sebagai pengeluaran biaya perusahaan. Maka dengan demikian, perbandingan harga/biaya sebelum dan sesudah menggunakan VPN terlihat jelas bahwa dengan menerapkan VPN pada kantor pusat dan kantor cabang cukup menghemat biaya komunikasi yang perlu dikeluarkan oleh perusahaan House Printing untuk bulanbulan selanjutnya.
Perbandingan Harga Sebelum dan Sesudah Implementasi VPN

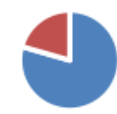

- $150 \mathrm{Mbps}$ First Media

- $250 \mathrm{Mbps}$ PT. Delta Nusa ntara Networks

Gambar 28. Gafik Perbandingan Harga sebelum dan sesudah implementasi VPN

\section{KESIMPULAN}

Dengan kondisi perusahaan yang masih dalam tahap mengembangkan bisnisnya antar cabang, terlebih dalam kondisi pandemic yang masih belum berakhir, penulis menjadikan penelitian ini sebagai salah satu solusi untuk meminimalisir biaya komunikasi perusahaan dari pengeluaran biaya selama tahun 2020 dan tahun-tahun sebelumnya. Selain itu, sebagai satu tindakan untuk mempercepat kinerja perusahaan dalam hal transfer data tanpa harus mengeluarkan biaya lebih. Tidak memungkinkan untuk perusahaan berkembang jika menerapkan cloud storage tanpa diimbangi dengan profit yang signifikan.

Maka penulis menjadikan implementasi VPN menjadi solusi utama untuk House Printing dalam hal mempercepat transfer data dengan penambahan biaya diawal untuk membeli perangkat penunjang dan pengurangan setiap bulannya pada paket ISP di kantor pusat. Dengan terwujudnya implementasi VPN ini, diharapkan dapat menghubungkan antar karyawan agar bisa mengakses data kebutuhan kantor antar cabang setiap saat dan darimanapun karyawan berada.

\section{REFERENSI}

[1] S. Ikhwan and A. Amalina, "Analisis Jaringan VPN Menggunakan PPTP dan L2TP," J. Infotel, vol. 9, no. 3, pp. 265270, 2017, doi: 10.20895/infotel.v9i3.274.

[2] F. Ardianto, "Penggunaan mikrotik router sebagai jaringan server," Pengguna. Router Mikrotik, no. 1, pp. 26-31, 2020.

[3] F. Bensalah, N. El Kamoun, and A. Bahnasse, "Analytical performance and evaluation of the scalability of layer 3 tunneling protocols: case of voice traffic over IP," IJCNS Int. J. Comput. Sci. Netw. Secur., vol. 17, no. 4, pp. 361-369, 2017.

[4] I. Nurhaida and Ngadiyono, "Quality of service for traffic monitoring system based on static routing using EoIP tunnel over IPSec," ACM Int. Conf. Proceeding Ser., no. 1, pp. 91-99, 2019, doi: $10.1145 / 3314527.3314543$.

[5] S. T. Aung and T. Thein, "Comparative Analysis of Site-to-Site Layer 2 Virtual Private Networks," 2020 IEEE Conf. Comput. Appl. ICCA 2020, pp. 3-7, 2020, doi: 10.1109/ICCA49400.2020.9022848

[6] B. A. Widodo, "Analisis Quality of Service pemanfaatan Ethernet Over IP(EoIP) Tunnel di MikrotikRouterOS dengan Routing Protocol OSPF," J. Informatics, Inf. Syst. Softw. Eng. Appl., vol. 1 no. 1, pp. 1-8, Sep. 2018, doi: 10.20895/inista.v1i1.17.

[7] B. L. Hartawati, P. Studi, T. Informatika, F. I. Komputer, and U. Brawijaya, "Implementasi IoT Data Storage Dengan Menggunakan Sistem Basis Data Terdistribusi Berbasis MySQL Cluster," vol. 5, no. 7, pp. 2986-2993, 2021. 
[8] A. Tedyyana, R. Kurniati, P. Studi, and P. Negeri, "Membuat Web Server Menggunakan Dinamic Domain Name System Pada IP Dinamis," Membuat Web Serv. Menggunakan Din. Domain Name Syst. Pada IP Din., no. Februari, pp. 1-10, 2016.

[9] E. Mufida, D. Irawan, and G. Chrisnawati, "Remote Site Mikrotik VPN Dengan Point To Point Tunneling Protocol (PPTP) Studi Kasus pada Yayasan Teratai Global Jakarta," J. Matrik, vol. 16, no. 2, p. 9, 2017, doi: 10.30812/matrik.v16i2.7.

[10] Y. Sawitra, P. Nugroho, E. Firmansyah, W. Dewanto, and R. Hartanto, "Design of a Low Cost High Efficiency Multiple Output Self Oscillating Flyback Converter," vol. 1, no. 2, 2017.

[11] I. P. Hariyadi, "Sentralisasi Manajemen Hotspot Menggunakan Transparent Bridge Tunnel EoIP over SSTP,” J. Matrik, vol. 16, no. 2, p. 86, 2017, doi: 10.30812/matrik.v16i2.8.

[12] A. P. Sari and N. Kemala, "Perancangan Jaringan Virtual Private Network Berbasis Ip Security Menggunakan Router Mikrotik," vol. 7, no. 2, pp. 150-164, 2020.

[13] N. Lizarti, "Aplikasi Network Traffic Monitoring Menggunakan Simple Network Management Protocol ( SNMP ) pada Jaringan Virtual Private Network ( VPN ) Menggunakan Simple Network Management Protocol ( SNMP ) pada Jaringan Virtual Private Network ( VPN ) Wirta Agustin," no. June 2015, 2018.

[14] E. Suryani and S. N. R. Honey, "Implementasi Virtual Private Network - Wan Dalam Dunia Bisnis," JUTI J. Ilm. Teknol. Inf., vol. 6, no. 1, p. 31, 2007, doi: 10.12962/j24068535.v6i1.a185.

[15] S. Hidayatulloh and R. A. F. Adam, "Implementasi Intercity Berbasis Tunneling Mikrotik Menggunakan Metode Eoip Tunnel," J. Teknoinfo, vol. 14, no. 1, p. 66, 2020, doi: 10.33365/jti.v14i1.327.

[16] “侯 谦 1,2, 钟康惠 1 , 侯万雄 2 ，” vol. 37, no. 1, pp. 96100, 2017. 